\title{
An Attempt for the Exploration of Academicians' Experiences of the Standard Foreign Language Tests Held in Turkey through Metaphors
}

\author{
Savaş Yeşilyurt ${ }^{1}$ \\ ${ }^{1}$ Atatürk University, Faculty of Education, English Language Teaching Department, Turkey \\ Correspondence: Savaş Yeşilyurt, Atatürk University, Faculty of Education, English Language Teaching Department, \\ Turkey
}

Received: March 29, 2016

Accepted: April 18, 2016

Online Published: April 19, 2016

doi:10.5430/ijhe.v5n2p263

URL: http://dx.doi.org/10.5430/ijhe.v5n2p263

\begin{abstract}
The purpose of this study is to explore academicians' perceptions and experiences about the public high-stakes Foreign Language Test(s) (YDS, formerly UDS, KPDS, and their counterparts in different times and contexts) used to measure foreign language proficiency in Turkey. For this purpose, data were collected from academicians with different titles, genders, and ages through a survey in which they were asked to complete the sentence "The FLT is like_ for me because " with a one-or-two-word metaphor and a short sentence explaining their reason for the metaphor they choose. Of the over 2600 academicians the survey forms were sent to through an e-mail, 110 filled-in the forms. The data obtained were analyzed verbally and 34 different metaphors were collected. After the analysis of the metaphors, it was drawn that academicians generally have negative feelings and experiences about the foreign language test(s).
\end{abstract}

Keywords: Foreign Language Test, Metaphor, Academicians, Perceptions

\section{Introduction}

Research on foreign language teaching in Turkey indicates a general inefficiency and it is widely reported that despite long years, sources, and efforts allotted for language teaching, even university graduates do not have the desirable level of English proficiency (Alagözlü, 2012) to meet even their primary-level communication needs (Paker, 2012) in this language. Therefore, to search the status of foreign language teaching, explore the reasons underlying the difficulties and problems, and find ways of overcoming these difficulties and problems, several studies were conducted on this issue (Can \& Can, 2014; Demirpolat, 2015; Haznedar, 2004; Işsk, 2008).

In one of the studies which focused on this problematic status of language teaching and tried to figure out the reasons behind this status, Solak and Bayar (2015), based on the qualitative data obtained from university students, introduced a list of major challenges in foreign language teaching/learning in Turkey. The participants of this study related these challenges to a number of factors such as language skills, method, approach, practice, linguistic differences in two languages, personal differences, teacher, material, family and environment. Most of the participants summarized their experience of language learning as almost a complete failure. Alagözlü (2012), who defined EFL education in her title as cul-de-sac, held the same issue from the perspectives of academicians in a qualitative research and summarized the sources of problems in language teaching under four main themes as follows: "(1) flaws in Turkish educational system in general, inconsistency in foreign language education policy in particular; (2) learner and learning environment oriented issues; (3) indeterminacy in teaching methodology at schools; and (4) obstacles in language teacher training and maintaining their quality" (p. 1759). In another study, which aimed to evaluate the primary school English textbooks, Haznedar (2009) presented a collection of the sources of the serious problems in foreign language teaching. She pointed to the factors such as the inadequate number of well qualified teachers, overcrowded classrooms, insufficiency of teaching materials, and the approaches focusing on grammar and not effectively benefitting from the techniques promoting the skills to use language. Işı (2008) also defined the process of language teaching as a serious problem because of the inefficiencies due to the use of conventional teaching practices and problems in language education. These studies agree on the seriousness and multi-faceted nature of the problems in foreign language teaching in Turkey.

However, among the studies on the challenges in foreign language teaching in Turkey carried out up to now, only few revolved around academicians' language learning experiences or the foreign language tests they generally take, 
which is the main concern of this study. In Turkey, academicians need to take high-stakes foreign language tests (FLTs) (YDS, until 2013 UDS and/or KPDS), which are multiple- choice tests aiming to measure, in broad terms, test-takers' knowledge of grammar and vocabulary, translation skills, and reading comprehension (Kıray, 2015), for some reasons or purposes. Akpınar and Çakıldere (2013) list these reasons as attending a PhD program or in some universities applying for MA or MS programs, getting promotion in their academic career or applying for different positions such as research assistant, lecturer, assistant professor, and associate professor and getting an increment in their salaries. Therefore, these foreign language tests play a great role in academicians' career.

In this respect, some studies were carried out to evaluate the FLTs in Turkey. One group of studies aimed to assess these tests in terms of their structure and content (Aşkaroğlu, 2013; Gür, 2012; Kıray, 2015). The other group dealt with them by searching test-takers' perceptions of such tests or their effects (Akpınar \& Çakıldere, 2013; Yavuzer \& Göver, 2012). In one of the studies in the latter group, which is more relevant to the issue under inquiry in this study, Akpınar and Çakıldere (2013) aimed to explore the reflections of high-stakes language tests on academicians' four language skills. The results of the study revealed that these tests had positive effects on only reading skill while, since the tests and the process of preparing for them do not require the test-takers to study and improve listening, speaking, and writing skills, they had negative effects on the other skills. In another study, Yavuzer and Göver (2012) attempted to explore academicians' levels of achievement in such tests and their perceptions of them. The findings of their study showed a general success in FLTs among the participants. However, participants' opinions were similar to those obtained in the study of Akpınar and Çakıldere (2013) in that they found the FLTs inadequate as they neither measure language skills nor contribute to the development of these skills and the use of language effectively.

When taken together it can be suggested that the studies on both foreign language teaching in general and high-stakes foreign language tests in Turkey indicate the problems or gaps through all aspects and stages from policy making or planning to testing and evaluation. Among the others, the most frequently mentioned issues are teaching, developing, measuring and using four language skills, in particular listening, speaking, and writing and use of English (or other foreign languages taught) for real communicative purposes. In the following sections, some more studies dealing with these issues will be presented to the extent they relate to the main focus of this study, which is "academicians' experiences of preparing and taking high-stakes foreign language tests".

\subsection{Use of Metaphor as a Tool in Educational Research}

Metaphor, defined by Lakoff and Johnson (2003) as "understanding and experiencing one kind of thing in terms of another" (p. 6), has been widely used as a means of research to explore people's perceptions, beliefs, feelings, or experiences related to different phenomena in numerous disciplines and areas in life in recent years besides being a phenomenon as a subject matter or an instrument of several different areas of study such as semantics, pragmatics, discourse analysis, language, literature, philosophy, and psychology (Ritchie, 2013) .

In this respect, metaphors are widely used by education researchers and scholars as well (Çelikten, 2006; Mouraz, Pereira, \& Monteiro, 2013; Özdemir \& Akkaya, 2013; Saban, 2006; Seferoğlu, Korkmazgil, \& Ölçü, 2009), seemingly because of their potential of helping people understand and make themselves be better understood by the others by solidifying the ideas or things with the use of better or already known images. The other possible reason for such tendency would be that, besides making understanding easier, metaphors also give ideas about how people conceive the world or things and this is important because people act accordingly (Lakoff \& Johnson, 2003). Indeed, in educational settings, the metaphors that teachers or students use to describe different factors or aspects of education would enlighten their conceptions and accordingly their practices (Zheng \& Song, 2010). This would contribute to diagnosing problems, and in fact diagnosing or naming problems is the first step of finding solutions just as diagnosing an illness is the first step of treatment because giving something the right name enables us to have control over it (Peck, 1983, p.114). For such reasons, metaphor analysis has become a common instrument of research in education for the inquiry of its different elements or aspects. In this regard, the studies in the field of education mainly revolved around the phenomena such as school (Özdemir \& Akkaya, 2013; Saban \& Keleşoğlu, 2011; Toker-Gökçe \& Bülbül, 2014), teaching (Alger, 2009), learning (Farjami, 2012; Kırmızı \& Çelik, 2015), teacher (Goldstein, 2005; Seferoğlu, Korkmazgil, \& Ölçü, 2009), coursebook (Kesen, 2010; McGrath, 2006), a certain subject (Güven \& Güven, 2009) or a subject matter in a course (Font, Bolite, \& Acevedo, 2010; Groth \& Bergner, 2005), or a concept in education (Babacan, 2014; Derman, 2014).

As for foreign language research, among these educational studies, there are also ones which specifically used metaphors as a tool of research for the issues concerning English language teaching. One of such studies is McGrath (2006)'s search into Brazilian English teachers' views of their English language teaching textbooks. He reported 221 images or metaphors for textbooks under five main themes (guidance, access, support, resource, and constraint) and 
the metaphors with the highest frequencies were listed as tool, guide, path, and map. A similar research was carried out by Kesen (2010). She asked her participants, 150 Turkish learners of EFL who were university students at the time of the study, to describe their English coursebook with metaphors. The participants produced 57 different metaphors clustered by the researcher under 15 themes. Although they reflected some negative perceptions of the coursebooks in their metaphors, most of the metaphors produced were identified to hold positive connotations. In another study which used the metaphor elicitation technique, Kamberi (2014) aimed to explore university students' metaphors about learners, teachers, and their major, English. The findings obtained indicated a general satisfaction with all the three factors. The majority of the metaphors were reported to be positive (e.g. water, flower for teacher; flower, star for students; and, sky, window for English). In a study investigating adult Iranian learners' metaphors and images about foreign language learning, Farjami (2012) listed 229 metaphors clustered under 23 themes. Depending on these metaphors, he emphasized participants' positive attitudes to foreign language learning. The first five of the themes he listed according to their frequency can be taken as a justification for this inference: exploration (56), sports and physical activity (28), journey (22), food, cooking and eating (19), and personal growth/identity renewal (15). Likewise, in their research on both pre-service and in-service English teachers, Seferoğlu, Korkmazgil, and Ölçü (2009) tried to figure out their conceptualizations of teacher through metaphor elicitation method. Their overall presentation of the metaphors revealed a tendency to describe teachers as a guide, a facilitator, and a resource person which can be attributed to both pre-service and in-service teachers' positive perceptions of the concept of teacher.

All these studies revealed the usefulness of metaphor analysis as a tool of research in foreign language education as well as in other areas of education. Metaphor analyses or metaphors are useful for also enlightening the conceptions and experiences of different parties in the process of education and reflecting their practices. Therefore, they can be contributory to the diagnosis, treatment, and solution of the problems in education in general and specifically in foreign language teaching and learning.

Under the light of the relevant literature, this study was conducted to explore academicians' perceptions about FLTs and their experiences, i.e. to deepen the understanding about FLT phenomenon through metaphor elicitation.

\section{Methodology}

The research method used in this study can be regarded as a phenomenological research, which is a type of qualitative research and defined by Cresswell (1998) as "the description of the meaning of the lived experiences for several individuals about a concept or the phenomenon" (p.51) and in which the investigator collects data from individuals who have experienced the phenomenon under investigation (ibid. p. 54). In addition, the technique used for the data collection and analysis of the study is specifically the metaphor analysis, in another word, metaphor elicitation technique.

\subsection{Participants}

In the broadest sense, the target group for this study was academicians. Accordingly, academicians from different faculties and majors and with different genders, ages, and titles were intended to be involved in the study. For convenience, Atatürk University, for which the researcher works, was chosen as the site of the research. It was planned to involve all the academicians of Atatürk University in the study in order to form a pool of metaphors as great as possible.

However, among all the academicians to whom the data collection instrument was sent, only 110 (35 female and 75 male) filled in the survey. The 110 participants were held as the sample (participants) of the study. Out of 110 participants, 70 (48 male and 21 female) from 17 different faculties and 2 vocational schools produced metaphors for the Foreign Language Test(s). Furthermore, it is possible to say that the sample was selected randomly and on a complete voluntary basis because the participants were only those who chose to respond the survey.

The tables below show the distribution of the participants of the study who filled in the survey and those who generated metaphors by the variables age and title. 
Table 1. Distribution of the participants who filled in the questionnaires and those who generated valid metaphors by age and titles

\begin{tabular}{|c|c|c|c|c|c|c|c|c|c|c|}
\hline AGE & & $21-25$ & $26-30$ & $31-35$ & $36-40$ & $41-45$ & $46-50$ & $51-55$ & $56+$ & TOTAL \\
\hline \multirow{2}{*}{ All participants } & $\mathrm{N}$ & 5 & 30 & 21 & 17 & 15 & 9 & 9 & 4 & 110 \\
\hline & Pct. & 4.55 & 27.27 & 19.09 & 15.45 & 13.64 & 8.18 & 8.18 & 3.64 & 100 \\
\hline \multirow{2}{*}{$\begin{array}{l}\text { Participants } \\
\text { generated } \\
\text { metaphors }\end{array}$} & $\mathrm{N}$ & 2 & 20 & 14 & 13 & 7 & 5 & 6 & 1 & 68 \\
\hline & Pct. & 2.94 & 29.40 & 20.58 & 19.18 & 10.28 & 7.34 & 8.82 & 1.46 & 100 \\
\hline TITLE & & Prof. & $\begin{array}{l}\text { Assoc. } \\
\text { Prof. }\end{array}$ & $\begin{array}{l}\text { Assist. } \\
\text { Prof. }\end{array}$ & $\begin{array}{l}\text { Res. } \\
\text { Assist. }\end{array}$ & Instructor & Expert & TOTAL & & \\
\hline \multirow{2}{*}{ All participants } & $\mathrm{N}$ & 15 & 14 & 35 & 38 & 7 & 1 & 110 & & \\
\hline & Pct. & 13.64 & 12.73 & 31.82 & 34.55 & 6.37 & 0.91 & 100 & & \\
\hline \multirow{2}{*}{$\begin{array}{l}\text { Participants } \\
\text { generated } \\
\text { metaphors }\end{array}$} & $\mathrm{N}$ & 10 & 7 & 20 & 27 & 4 & - & 68 & & \\
\hline & Pct. & 14.71 & 10.29 & 29.41 & 39.71 & 5.88 & - & 100 & & \\
\hline
\end{tabular}

As seen in Table 1, there were participants, whether produced metaphors or not, from a wide range of age groups and titles. The majority of the participants were aged between 26 and 45 (83 out of 110 and 51 out of 68 ). As for the titles, there were participants with different titles such as professor, associate professor, assistant professor, research assistant, instructor, and expert. Except for the expert, all the participants with different academic titles generated metaphors.

Although the findings of the current study will not be evaluated in relation to the variables introduced in the table, it is valuable as it shows the representativeness of the sample in terms of the ages and titles of participants.

\subsection{The Instrument}

To collect the data, a metaphor elicitation instrument was used. The reason underlying this choice is to keep the demand from the participants as little as possible and make them spend the least time possible (three to five minutes). This was supposed to make much more academicians willing to participate in the research and generate metaphors and one-sentence explanations or justifications for them. Therefore, a short survey including items aiming to obtain basic demographic information about the participants and the sentence "The FLT is like for me because

"which required the participants to fill in the blank with a metaphor and write a sentence for justifying why they chose to generate that metaphor was employed. While deciding on the instrument and its content, some previous studies which used metaphors as their data collection tool (McGrath, 2006; Saban, 2006) were utilized. There were also items asking about how many times they took the FLT(s) and their scores from the last test they took. The instrument was prepared in Turkish to enable participants to communicate their opinions or feelings freely.

\subsection{Data Collection Procedure}

The data of this study were collected towards the end of 2014 over a period of one month. First, with a written formal application, the necessary written permission for the research was granted and the support of the University for sending the data collection instrument to all the academicians, in different faculties, institutes, high schools, vocational schools, and research centers of the university, through their emails was asked from the university management. The Computer Science Application and Research Center contributed to the researcher to deliver the data collection instrument to all of the academicians at a time. Therefore, an email including the link for an online survey was sent to them. In case some academicians might see the e-mail or fill in it later, the researcher waited for more than one month to end the data collection procedure and start data analysis. As said before, 110 academicians 68 of whom generated metaphors filled in the survey and the data of this study consisted of the metaphors and one-sentence reasons for using the metaphors generated by these academicians.

\subsection{Data Analysis}

The data collected, computerized and later transcribed was undergone a content analysis by the researcher several times at certain intervals and by two more different raters. After careful analyses, it was agreed that of the 110 respondents only 68 generated valid metaphors. All other respondents' descriptions of the foreign language test were identified not to be more than the expressions "difficult test", "invalid examination" and more of the same; therefore, they were not regarded metaphors and excluded from the main data analysis and presentation process. As to the rest 34 different and, in sum, 68 metaphors produced by the participants, first they were grouped according to whether they hold positive, negative or no positive or negative associations (as positive, negative, and neutral themes). Under 
these three main headings were listed the themes and categories belonging to these themes. In grouping themes, besides literal meanings of the metaphors, the explanations offered for why the participants generated such metaphors were benefited. In the steps, metaphors and the explanations for them were translated into English. Both the analysis and translation of the data were done upon the consensus among the raters.

\section{Results and Discussion}

The data analyzed are introduced in Table 2 below and the paragraphs following it. First, the positive, negative, and neutral themes, the categories under these themes with their frequencies, the average numbers of the tests taken, and average scores of the participants who produced the same metaphors are given in the table. Second, these findings are explained and supported with the extracts from the explanations of the participants.

Table 2. Distribution of the positive, negative, and neutral metaphors

\begin{tabular}{|c|c|c|c|c|c|}
\hline & Themes & Categories & Fr. & $\begin{array}{l}\text { Number of } \\
\text { the tests }\end{array}$ & $\begin{array}{l}\text { Average } \\
\text { scores }\end{array}$ \\
\hline \multirow{8}{*}{$\begin{array}{l}\text { POSITIVE } \\
\text { THEMES }\end{array}$} & \multirow[t]{2}{*}{ FLT as a fun } & Hobby & 2 & 6 & 83 \\
\hline & & Fun & 1 & 3 & 65 \\
\hline & \multirow{3}{*}{$\begin{array}{l}\text { FLT as a mental } \\
\text { activity }\end{array}$} & Puzzle & 3 & 3 & 78 \\
\hline & & Computer game & 1 & 10 & 85 \\
\hline & & $\begin{array}{l}\text { Mathematical } \\
\text { formula }\end{array}$ & 1 & 5 & 67 \\
\hline & \multirow[t]{2}{*}{ FLT as a necessity } & Bread and water & 1 & 3 & 74 \\
\hline & & Must & 1 & 6 & 74 \\
\hline & FLT as a tool & $\begin{array}{l}\text { Door/window to } \\
\text { the world }\end{array}$ & 1 & 3 & 65 \\
\hline \multirow{21}{*}{$\begin{array}{l}\text { NEGATIVE } \\
\text { THEMES }\end{array}$} & \multirow[t]{4}{*}{ FLT as a barrier } & Obstacle & 12 & 5 & 65 \\
\hline & & Formality & 4 & 5 & 69 \\
\hline & & Mountain & 3 & 4 & 71 \\
\hline & & Wall & 1 & 10 & 66 \\
\hline & \multirow[t]{4}{*}{ FLT as a diversion } & Bottomless pit & 1 & 20 & 55 \\
\hline & & Marathon & 1 & 6 & 65 \\
\hline & & Treasure hunting & 1 & 3 & 65 \\
\hline & & $\begin{array}{l}\text { Unattainable } \\
\text { dream }\end{array}$ & 1 & 4 & 60 \\
\hline & \multirow{6}{*}{$\begin{array}{l}\text { FLT as a state of } \\
\text { feeling }\end{array}$} & Nightmare & 4 & 8 & 47 \\
\hline & & Bother & 2 & 5 & 63 \\
\hline & & Stress & 2 & 5 & 69 \\
\hline & & Anxiety & 1 & 7 & 68 \\
\hline & & Bad memory & 1 & 4 & 65 \\
\hline & & Weariness & 1 & 10 & 57 \\
\hline & \multirow{5}{*}{$\begin{array}{l}\text { FLT as an external } \\
\text { trouble }\end{array}$} & Torture & 6 & 8 & 59 \\
\hline & & Pain in the neck & 3 & 18 & 56 \\
\hline & & Fault & 1 & 5 & 75 \\
\hline & & Jealous relative & 1 & 4 & 54 \\
\hline & & $\begin{array}{l}\text { Sword } \\
\text { Damocles }\end{array}$ & 1 & 2 & 71 \\
\hline & \multirow[t]{2}{*}{ FLT as a tool } & Broken scale & 1 & 5 & 60 \\
\hline & & $\begin{array}{l}\text { Trivial but handy } \\
\text { tool }\end{array}$ & 1 & 6 & 55 \\
\hline \multirow{5}{*}{$\begin{array}{l}\text { NEUTRAL } \\
\text { THEMES }\end{array}$} & \multirow[t]{4}{*}{ FLT as a means } & Bridge & 4 & 5 & 63 \\
\hline & & Hotel & 1 & 4 & 68 \\
\hline & & Key & 1 & 8 & 48 \\
\hline & & Tool & 1 & 10 & 66 \\
\hline & FLT as an uncertainty & Mysterious trip & 1 & - & - \\
\hline
\end{tabular}


The metaphors listed in Table 2 will be introduced and explained separately and respectively in the following sections according to the positive, negative, or neutral connotations they hold. It is essential to note that the metaphors are introduced below with their frequencies in parenthesis next to them.

\subsection{Positive Metaphors}

There are only eleven positive metaphors. They were clustered under four themes: (1) FLT as a fun, (2) FLT as a mental activity, (3) FLT as a necessity, and (4) FLT as a tool.

The first theme in this group is FLT as a fun (3); two participants named FLT and the process of studying for FLT as hobby (2) and one as fun (1). The respondents who generated the metaphor hobby justified their reasons in the following sentences as: "I like using a foreign language"; "Learning new languages and words develop people"; and the use of fun as a metaphor was explained as: "It is fun because it led me to read English stories in the preparation process". Here the participants form an association between FLT tests and things they have pleasure with or enjoy doing. These metaphors are similar to the one "game that makes us feel good" for English presented in Kamberi (2014).

The second theme FLT as a mental activity (5) involves three metaphors, puzzle (3), computer game (1), and mathematical formula (1). The words of one of the respondents clearly summarize the reasons underlying the use of puzzle to describe FLT: "You can reach the results step by step by putting the right parts in the right places". Other respondents also emphasized putting parts together and step-by-step process as the similarities between FLT and puzzles. Puzzle was regarded to have positive connotations because respondents claimed that knowing how to put the parts in the right places makes passing the examination very easy. For the metaphors computer game and mathematical formula, the following reasons were provided respectively: "I always enjoyed studying English...I never regarded it as an obligation but a real need and a real cultural element..." and "English is perceived as a technical language". Computer game and (solving) puzzle were also among the metaphors reported in Farjami (2012).

The third positive theme is FLT as a necessity (2). The metaphors under this theme are bread and water (1) and must (1). One participant defined FLT as bread and water because, to his expressions, "There is no way to continue one's career as an academician other than passing the FLT just as there is no way to keep alive without drinking and eating." The respondent who generated the metaphor must, put forward a similar reason as "It is necessary for academicians".

The last theme with positive connotations is FLT as a tool (1) including the metaphor door/window to the world (1) the explanation for which was "It is the first key to confidence for me".

Overall, the average numbers of the tests taken and the average score the participants got from the last examination they attended are respectively 4.64 and 75.5. Considering the foreign language criterion for associate professorship which is 65 from the FLT (or its equivalent from another standard test), the level of success of the participants who generated positive metaphors in this test can be said to be quite high. This can be interpreted as an association between having passed the exam and positive conceptions of the test.

\subsection{Negative Metaphors}

The majority (49 out of 68 ) of the metaphors generated by academics for the FLT are negative. The negative metaphors were collected under five main themes as (1) FLT as a barrier, (2) FLT as a diversion, (3) FLT as a state of feeling, (4) FLT as an external trouble, and (5) FLT as a tool.

The first theme in this group is FLT as a barrier (20). Obstacle (12), formality (4), mountain (3), and wall (1) are the metaphors which construct this theme. Obstacle has the highest frequency among all. Most respondents see FLT as an obstacle both to academic and professional development and promotion and to scientific studies. They also emphasize that they cannot benefit from it in their area of study or in their professional life. The following three extracts exemplify why academicians see it as an obstacle clearly. One respondent said "Because of a language from which I will not benefit in my field of study much, I have to stop my academic studies". The other, highlighting the same points, added: "Before passing this test, you cannot go on your academic pursuits. In addition, I don't think this examination has academic benefits. Once you pass the test, it has no contribution to your academic studies". Another respondent emphasized the magnitude of this obstacle in the following words: "It stood in front of me as a "huge mountain' in a 13-year part of my life". Some other participants who generated the metaphor obstacle for FLT underlined also the low level of quality of the test itself and foreign language education system. The second metaphor in this group is formality. One of the reasons underlying the formation of such a metaphor put by one participant is "...In FLT (YDS), test-takers may encounter words that are irrelevant to their major and they will 
never use in the future so they regard this examination as only criterion to meet". Another respondent explained why he saw this test as a formality in the following words: "It is held just for elimination. It does not measure test-takers' knowledge... Namely, it is not a good measure of proficiency". The reasons put forward by the third respondent who produced the same metaphor were in line with the others: "I think it is inadequate to measure functional use of language". The third metaphor used here is mountain. The three academicians who used this metaphor based their justifications around the expression "difficult to overcome". The most comprehensive one is given in the following statement. "It requires a lot of time, effort, a good mountaineer (teacher) to overcome it. Once you reach the top, it is the point you are asked to get and it is enough for the rest of your life". The metaphor mountain was generated by the participants in Kesen (2010) for the coursebooks of English and by the participants in Farjami (2012) for foreign language learning as well. The last metaphor under the same theme is wall. One participant used this metaphor since he thought "The FLT is like one of the hurdles before the athletes who try to finish the race first... language instruction should be different, not based on memorization but practice-oriented. Namely, it should not be like a wall to overcome". These types of metaphors were formed generally by the participants who saw the FLT as a barrier especially before their academic career.

The second theme of negative metaphors is FLT as a diversion (4) which involves bottomless pit (1), marathon (1), treasure hunting (1), and unattainable dream (1). These metaphors were categorized under the title of diversion because they have connotations to long and hopeless processes that distract people from their main goals. The following extracts from participants' explanations may help to understand the motives behind the formation of them. The justifications for these metaphors were respectively: "It is not a meaningful exam in which you cannot take the mark you deserve. Even if you take the high enough score, this does not mean you know English"; "You need to run until the finish non-stopping. And the finish is taking 65 in the test"; "(The respondent first summarizes the ineffective foreign language education in Turkey and then emphasizes the difficulty for the academics to be successful in foreign tests and mentions their search for good courses, teachers, or books upon what they hear from others.) They go here and there aimlessly as if they were hunting treasure and spend a lot of money. After the results are announced each time, academicians get disappointed and this results in distraction from the profession and burn out as in treasure hunters go from place to place, dig the earth and find nothing. Some who are very good at their major get absorbed in treasure hunting and forget their real academic pursuits... Some gave up hunting treasure and closed themselves in their offices whereas some still keep hunting treasure..."; and "Effective real use of English is possible only by staying abroad for one or more years and this means changing all my life which seems impossible." By the metaphors under this theme, long time throughout which academicians are distracted from their essential studies is clearly pointed.

FLT as a state of feeling (11) is the third negative theme. The six metaphors under this theme are nightmare (4), bother (2), stress (2), anxiety (1), bad memory (1), and weariness (1). These metaphors reveal the serious reflections of foreign language tests on the perceptions and feelings of academics. The following extracts from the explanations about why participants defined FLT with these metaphors may illustrate these perceptions and feelings better. One justification put forward for the metaphor nightmare was as follows: "It is the biggest obstacle in front of my academic pursuits". The other reason was worded in the expressions "For some reasons, I cannot study sufficient enough... Examination time is not long enough... The questions are not relevant to our field of study." Another participant pointed to similar problems in his following words: "Because of English I cannot spare time for my academic development and scientific studies". Two participants stated they saw the FLT as a bother and explained their reasons as "I cannot memorize vocabulary" and "It took six years of my life away". The third metaphor in this group is stress. Two participants defined it a source of stress and expressed their justifications for it as "Its system and rules change very often and it stresses me out" and "Since the examination was held in Ankara in that time, travels and accommodations were very wearisome and stressful both economically and psychologically". One participant generated the metaphor anxiety and explained it as "It is necessary to pass this examination to get tenure and this makes me experience high levels of anxiety". Another metaphor in this section is bad memory. One participant attributed his cervical discal hernia to the process of preparing for the FLT. The last metaphor of this theme is weariness. The reason for this metaphor was given as "...Many times... 5 minus or 5 plus... Every time, the same result..." In their study, Yavuzer and Göver (2012) draw attention to the relation between the failure in tests and the stress and anxiety that the academicians experience. The same relationship can be inferred from the metaphors and the explanations for them under the theme FLT as a state of feeling.

The fourth theme consisting of negative metaphors is FLT as an external trouble (12). The metaphors in this group are respectively torture (6), pain in the neck (3), fault (1), jealous relative (1), and sword of Damocles (1). For different reasons, six participants proposed torture as a metaphor for the FLT. Some of these reasons can be seen in 
the following extracts: "I do not think this examination adds anything to my knowledge of English"; "Although I want to learn English, I don't think this examination contributes to learning it... When failed by one or two points, people need to restart preparing for it from the very beginning..."; "It is difficult and an imposition"; "It is a test consisting of the questions difficulty levels of which were deliberately increased to prevent people from being successful, and what it measures is not clear... It is a great obstacle in front of academicians and researchers... It is an examination with no counterpart in the world..."; "It is a meaningless and an illogical test which I believe measures neither my knowledge nor skills". Pain in the neck is another metaphor in this theme. This metaphor was justified by the following expressions: "People with very low level of proficiency are suddenly involved in a pain-in-the-neck process of foreign language exam...Tests are too difficult"; "They ask for what does not exist". The next metaphor is fault which was supported by the words as follows: "I find it a wrong practice imposed to the academicians, with the examination systems through which we cannot develop our speaking and writing skills and which are based on grammar and test techniques". The metaphor jealous relative was explained by the respondent who produced it in the following words: "Although I know, it always insists that I don't know English, it forces more and more and engages my mind." The last metaphor under the theme of FLT as an external trouble is the idiom sword of Damocles which is defined as "a bad or unpleasant thing that might happen to you at any time and that makes you feel worried or frightened" (see "Oxford Advanced Learner's Dictionary of Current English," 2015). The reason underlying the construction of this metaphor was expressed as "If I cannot pass it, my academic life will be incomplete". These metaphors point to external reasons for learning English and attending English test which contradict the intrinsic and personal reasons highlighted by the findings of Farjami (2012).

The last negative theme, FLT as a tool (2) includes two different metaphors: broken scale (1) and trivial but handy tool (1). The respondent who generated the former one offered the following justification for his choice: "The system of testing and evaluation is based on memorization rather than teaching"; and the reason put forward for the latter was "I don't think it means so much in terms of what it measures... It is an examination in which even very proficient people cannot take high marks... I don't think it is a high quality test which was designed to measure real proficiency level of English..."

The metaphors with negative connotations may be evaluated in relation to average numbers of the tests taken and the average score the participants got from the last examination they attended. They can be calculated to be 6.78 and 62.4 respectively. When compared to the average score (75.5) of the participants who produced positive metaphors, the levels of success of the participants who offered the metaphors with negative connotations is much lower. This may refer to an interrelationship between the scores from the FLTs and academicians' perceptions or conceptualizations of them.

\subsection{Neutral Metaphors}

Eight of the metaphors were classified as neutral metaphor because they have no direct positive or negative connotations. Two different themes, (1) FLT as a means and (2) FLT as an uncertainty, were formed in this group.

There are four different metaphors in the first theme, FLT as a means (7). They are bridge (4), hotel (1), key (1), and tool (1). The use of the metaphor bridge was explained by the participants who generated it in the following extracts: "The language of science is English so it is an area all academicians need to be successful. Namely, FLT is bridge to cross to be a good academician"; "It is not possible to achieve goals before passing this bridge"; "It is an examination academicians have to pass to achieve their goals even if they do not know the foreign language"; "It allows me to go to the other side; it is a tool I will never use again once I cross it". One respondent defined FLT as a hotel and explained his reason as "Language is a medium of science. It is useful when needed... Another metaphor is key (1) and the reason for the choice to use it was exemplified as "There are lots of keys in your keyholder and there is especially one among them which you never use in daily life or throw away. You know one day you will need it; sometimes you forget there is a key there and sometimes you remember it and say "I can use when I need it". However, that time you realize it is useless anymore, and you need a new one". The last metaphor tool was accompanied by the following words: "It is an obstacle that academicians have to overcome in academic career".

The theme of FLT as an uncertainty has one metaphor, mysterious trip (1). This metaphor was produced by an academician who had not taken this test yet. She stated "I have not taken the FLT yet. I have neither started preparing for it nor had a look at the questions. So it is very difficult, for me, to guess whether it is an examination that I can pass with no difficulty or an uphill task awaits me".

For the neutral metaphors, participants' average number of tests and the mean score from these tests are respectively 6 and 59.1. The average score here is very close to that of the participants who produced negative metaphors. If average scores are compared on the basis of individual metaphors, more drastic relations can be 
detected, of course. For example, the average score of the participants who proposed the negative metaphor nightmare is by far the lowest (47). This can be an exemplification of the close reciprocal relation between what people experience and how they conceive things (Lakoff \& Johnson, 2008).

To sum up, the metaphors produced by the participants of this study for the foreign language test(s) in Turkey are overwhelmingly negative. Of 68 metaphors, $49(72.1 \%)$ have negative connotations. These metaphors are mainly related to the nature and quality of the test, the handicaps it causes, the value and necessity attributed to it, its reflection on real or academic life, its effects on human psychology, the preparation process for them, etc. Some of these factors are consistent with those in the previous studies (Akpınar \& Çakıldere, 2013; Yavuzer \& Göver, 2012). The time spent on these tests, the scores taken, and the experiences of the academicians during studying for them may be put forward as strong precedents of such conceptualizations and metaphors.

\section{Conclusion}

In this study, it was aimed to explore academicians' perceptions or experiences related to the standard foreign language tests they need to take and pass for some academic or professional reasons. For this purpose, via their email addresses, the participants were sent a questionnaire in which they were asked to write a metaphor for the FLT(s) and short justifications for the metaphor they generate. After the preliminary analysis of the data, 34 different and total 68 metaphors were determined. These metaphors were clustered in three groups of themes: positive, negative, and neutral themes. When the numbers of the metaphors in each group are considered, the dominance of negative ones over the others is quite obvious. The main results of the study can be summarized as follows.

- Academicians' metaphors about the FLT mainly point to their negative perceptions and experiences related to this test.

- These metaphors and the explanations for them reflect serious effects of this test on academicians' both personal and academic life.

- The negative metaphors about the FLT are generally associated with the questionable value, quality, and utility of this test and experiences in the process. Here, FLTs' lack of communicative side and contribution to real life or scientific purposes is highlighted.

- Some participants stated that they took the same test many times over a long period of time. The long exposure to this test and failures by one or two points may be assumed to strengthen their negative opinions and feelings about it.

- From the expressions of the participants, it is understood that most academicians try to overcome the "obstacle" by studying alone. So their current and previous experiences of foreign language learning might be one of the reasons underlying their negative feelings, conceptualizations, and, accordingly, metaphors about the FLTs.

- It is also possible to say that there is an interrelationship between the scores from the tests and the metaphors produced. Generally, metaphors holding negative connotations are used by the participants who had relatively lower scores from the FLTs.

There may be a two-way interaction between the metaphors generated and academicians' experiences or feelings related to FLTs and the other factors indicated. That is, one may be the precedent or antecedent of the others. In other words, as what people experience may shape their conceptualizations, their experiences may be shaped by their conceptualizations as well (Lakoff \& Johnson, 2008).

Depending on the main findings listed above, some pedagogical implications can be made. First, it is clearly seen that passing FLTs takes long time for many academicians and in this process they experience great difficulties which seriously influence their both personal and professional life. Second, participants report negative opinions about the structure, scope, quality, and utility of the tests. These two issues are clearly evidenced in most of the metaphors and explanations they proposed. These two points combined together may be said to have resulted in conceptualizations of the FLT as an obstacle to the scientific studies of participants.

Since the greatest mission of universities is to produce science, they need to support academicians in finding ways to overcome this obstacle. They need to take steps in order to change the negative conceptualizations of FLT and their nature to the better by adding communicative aspects of language to instructional and testing processes, organizing effective instructional practices, offering opportunities of learning to shorten the time and lessen the money and effort spent on foreign language learning process, and contributing the functionality and utility of English by 
integrating it into academicians' lives and professions. Namely, universities should take greater responsibility for finding systematic ways of overcoming the challenges in foreign language learning.

This study is significant since it presents valuable data on academicians' views, feelings, and experiences about high-stakes foreign language tests in Turkey. It also showed the usefulness of metaphor elicitation techniques in foreign language education research. However, it has limitations as well. For instance, it lacks representability since it was conducted with a limited number of participants from a single site. In addition, only one type of research design and only one of the metaphor elicitation techniques were used in data collection. Furthermore, the data could have been evaluated in relation to different variables and exposed to a deeper analysis, i.e. in the interpretation and categorization of the metaphors, the cultural aspects could have been taken into account.

In the future the same phenomenon can be explored from multiple perspectives by using different research designs and data collection tools with a greater group of participants from more contexts. Also, the phenomenon can be handled in relation to different variables such as gender, majors, or proficiency level. A larger scale longitudinal study may help to exploring the solid, realistic, practical, and beneficial ways of understanding and overcoming the difficulties and problems in foreign language learning processes and being successful in FLTs.

\section{Acknowledgments}

The author is grateful to Atatürk University and the participants of the research for their valuable support during the data collection process.

\section{References}

Akpınar, K. D. \& Çakıldere, B. (2013). Washback effects of high-stakes language tests of Turkey (KPDS and ÜDS) on productive and receptive skills of academic personnel. Journal of Language and Linguistic Studies, 9(2), 81-94. Retrieved from http://www.jlls.org/vol9no2/81-94.pdf

Alagözlü, N. (2012). English as a foreign language cul-de-sac in Turkey. Procedia-Social and Behavioral Sciences, 47, 1757-1761. http://dx.doi.org/10.1016/j.sbspro.2012.06.896

Alger, C. L. (2009). Secondary teachers' conceptual metaphors of teaching and learning: Changes over the career span. Teaching and Teacher Education, 25(5), 743-751. http://dx.doi.org/10.1016/j.tate.2008.10.004

Aşkaroğlu, V. (2013). 2013 YDS ile 2012 KPDS ve 2012 ÜDS sınavlarının karşılaştırılması (A Comparative study on YDS (2013), KPDS (2012), and ÜDS (2012)). Black Sea Journal, 21. Retrieved from http://dergipark.ulakbim.gov.tr/kdeniz/article/view/ 5000046729/ 5000044024

Babacan, E. (2014). AGLS öğrencilerinin müzik kavramına ilişkin algıları: metafor analizi (AGSL Students' Perception of Music Concept: Metaphor Analysis). Journal of Research in Education and Teaching, 3(1), 124-132. Retrieved from http://jret.org/FileUpload/ks281142/File/12.babacan.pdf

Can, E. \& Can, C. I. (2014). Türkiye'de ikinci yabancı dil öğretiminde karşılaşılan sorunlar (Problems encountered in second foreign language teaching in Turkey). Trakya University Journal of Education, 4(2). 43-63. Retrieved from http://dergipark.ulakbim.gov.tr/trkefd/article/view/5000082760/5000076943

Çelikten, M. (2006). Kültür ve öğretmen metaforları (Culture and teacher metaphors used in educational system). Sosyal Bilimler Enstitüsü Dergisi (Journal of Graduate School of Social Sciences), 21(2), 269-283. Retrieved from http://sbedergi.erciyes.edu.tr/sayi_21/16-\%20(269-283.\%20syf.).pdf

Cresswell, J. W. (1998). Qualitative inquiry and research design: Choosing among five traditions. London: SAGE Publications.

Demirpolat, B. C. (2015). Türkiye'nin yabancı dil öğretimiyle imtihanı: Sorunlar ve çözüm önerileri (Trial of Turkey with foreign language education: Problems and suggestions for solutions). Analiz (Analysis), 131, 1-19. Retrieved from books.google.com

Derman, A. (2014). Lise öğrencilerinin kimya kavramına yönelik metaforik algıları (High school students' metaphoric perceptions for the concept of Chemistry). Turkish Studies: International Periodical for the Languages, Literature and History of Turkish or Turkic,9(5), 749-776. http://dx.doi.org/10.7827/TurkishStudies.6738

Farjami, H. (2012). EFL learners' metaphors and images about foreign language learning. Studies in Second Language Learning and Teaching, 2(1), 93-109. http://dx.doi.org/10.14746/ssllt.2012.2.1.5 
Font, V., Bolite, J., \& Acevedo, J. (2010). Metaphors in mathematics classrooms: Analyzing the dynamic process of teaching and learning of graph functions. Educational Studies in Mathematics, 75(2), 131-152. http://dx.doi.org/10.1007/s10649-010-9247-4

Goldstein, L. S. (2005). Becoming a teacher as a hero's journey: Using metaphor in preservice teacher education. Teacher Education Quarterly, 32(1), 7-24. Retrieved from http://www.jstor.org/stable/23478686

Groth, R. E. \& Bergner, J. A. (2005). Pre-service elementary school teachers' metaphors for the concept of statistical sample. Statistics Education Research Journal, 4(2), 27-42. Retrieved from http://iase-web.org/documents/SERJ/SERJ4(2)_groth_bergner.pdf

Gür, Ö. (2012). Testing, assessment and KPDS (foreign language proficiency examination for state employees)-What does this exam assess? Sakarya University Journal of Education, 2(1), 23-32. Retrieved from http://suje.sakarya.edu.tr/article/view/ 1024000036/ 1024000036

Güven, B. \& Güven, S. (2009). İlköğretim öğrencilerinin sosyal bilgiler dersinde metafor oluşturma becerilerine ilişkin nicel bir inceleme (Quantitative analysis relating to forming of metaphor which was made in social studies lesson by primary school students). Kastamonu Education Journal, 17(2). 503-512. Retrieved from http://www.kefdergi.com/pdf/cilt17_no2_2009mayis/17_10.pdf

Haznedar, B. (2004). Türkiye'de yabancı dil öğretimi: İlköğretim yabancı dil programı (Foreign language education in Turkey: Primary foreign language curriculum). Boğaziçi University Journal of Education, 21(2). Retrieved from dergipark.ulakbim.gov.tr

Haznedar, B. (2009, May). Türkiye’de yabancı dil ĕğitimine ilişkin değerlendirmeler: İlkögretim İngilizce ders kitaplarının incelenmesi/Remarks on foreign language education policies in Turkey: A critical evaluation of primary English textbooks. Paper presented at the First International Congress of Educational Research "Trends and Issues of Educational Research, Çanakkale Onsekiz Mart University, Çanakkale. Retrieved from http://www.eab.org.tr/eab/2009/pdf/271.pdf

Işık, A. (2008). Yabancı dil eğitimimizdeki yanlışlar nereden kaynaklanıyor? (Where do the mistakes in foreign language education stem from?) Journal of Language and Linguistic Studies, 4(2), 15-26. Retrieved from http://dergipark.ulakbim.gov.tr/jlls /article/view/5000084181/5000078278

Kamberi, L. (2014). Using metaphors in language teaching and learning. European Journal of Research on Education, Special Issue: Contemporary Studies in Education, 92-97. Retrieved from http://iassr2.org/rs/020415.pdf

Kesen, A. (2010). Turkish EFL learners' metaphors with respect to English language coursebooks. Novitas-ROYAL (Research on Youth and Language), 4(1), 108-118. Retrieved from http://www.novitasroyal.org/Vol_4_1/kesen.pdf

Kiray, G. (2015). Macro-structure analysis of reading comprehension paragraphs of KPDS and YDS exams within years 2003-2013. Journal of the Hasan Âli Yücel Faculty of Education, 12(1), 219-233. Retrieved from http://dergipark.ulakbim.gov.tr/iuayefd/article/viewFile/5000121873/5000112183

Kırmızı, F. S. \& Çelik, D. (2015). İlkokul öğrencilerinin ilkokuma yazma öğrenme sürecine ilişkin metafor algıları (Elementary school students' metaphorical perceptions of the basal reading and writing process). Turkish Studies: International Periodical for the Languages, Literature and History of Turkish or Turkic, 10(10), 793-816. http://dx.doi.org/10.7827/TurkishStudies.8471

Lakoff, G. \& Johnson, M. (2008). Metaphors we live by. Chicago: University of Chicago press.

McGrath, I. (2006). Using insights from teachers' metaphors. Journal of Education for Teaching, 32(3), 303-317.

Mouraz, A., Pereira, A., \& Monteiro, R. (2013). The use of metaphors in the processes of teaching and learning in higher education. International Online Journal of Educational Sciences, 5(1), 99-110. http://dx.doi.org/10.1080/02607470600782443

Oxford Advanced Learner's Dictionary (2015) (9 ed.). Oxford: Oxford University Press.

Özdemir, S. \& Akkaya, E. (2013). Genel lise öğrenci ve öğretmenlerinin okul ve ideal okul algılarının metafor yoluyla analizi (The analysis of secondary school students' and teachers' mental images of school and ideal school by using metaphor). Educational Administration: Theory and Practice, 19(2), 295-322. Retrieved from http://dergipark.ulakbim.gov.tr/kuey/article/view/5000050479/5000047737 
Paker, T. (2012). Türkiye'de neden yabancı dil (İngilizce) öğretemiyoruz ve neden öğrencilerimiz iletişim kurabilecek düzeyde İngilizce öğrenemiyor? (Why cannot we teach foreign language (English) in Turkey and why cannot our students learn English at a level to communicate? Pamukkale University Journal of Education, 32(2), 89-94.

Peck, M. S. (2003). Kötülüğ̈̈n psikolojisi (People of the lie) (Göker Talay, Trans.) İstanbul: Eronus books.

Ritchie, L. D. (2013). Metaphor. Cambridge: Cambridge University Press.

Saban, A. (2006). Functions of metaphor in teaching and teacher education: A review essay. Teaching Education, 17(4), 299-315. http://dx.doi.org/10.1080/10476210601017386

Saban, A., \& Keleşoğlu, A. (2011). Bilgisayar öğretmeni adaylarının "okul” ve "bilgisayar öğretmeni” kavramlarına ilişkin zihinsel imgeleri (Prospective computer teachers' mental images about the concepts of "school" and "computer teacher). Educational Sciences: Theory \& Practice (ESTP), 11(1), 423-446.

Seferoğlu, G., Korkmazgil, S., \& Ölçü, Z. (2009). Gaining insights into teachers' ways of thinking via metaphors. Educational Studies, 35(3), 323-335. http://dx.doi.org/10.1080/03055690802648135

Solak, E. and Bayar, A. (2015), Current challenges in English language learning in Turkish EFL context. Participatory Educational Research (PER), 2(1), 106-115. http://dx.doi.org/10.17275/per.15.09.2.1

Toker-Gökçe, A., \& Bülbül, T. (2014). Okul bir insan bedenidir: Meslek lisesi öğrencilerinin okul algılarına yönelik bir metafor çalışması (Schools as a human body: A metaphor study related to perceptions about schools among vocational high school students). Journal of Educational Sciences Research,4(1), 63-88. http://dx.doi.org/10.12973/jesr.2014.41.4

Yavuzer, H., \& Göver, İ. H. (2012). Akademik personelin yabancı dil durumu ve yabancı dil sınavlarına bakışı: Nevşehir örneği (The foreign language level of academic staff and their attitudes toward foreign language exams: Nevşehir University case). Nevşehir Hacı Bektaş Veli University Journal of ISS, 1(2). 136-158. Retrieved from http://dergipark.ulakbim.gov.tr/nevsosbilen/article/view/1043000099/1043000057

Zheng, H. B., \& Song, W. J. (2010). Metaphor analysis in the educational discourse: A critical review. Online Submission, 8(9), 42-49. Retrieved from http://files.eric.ed.gov/fulltext/ED514704.pdf 